"'総 訜 REVIEW

\title{
金属材料の繰返し変形とそれに伴って生ずる転位組織"
}

幡中憲治**

\author{
Fatigue-Induced Dislocation Structures and Some Considerations \\ of Cyclic Deformation Behavior in Metals
}

by

\section{Kenji Hatanaka}

(Faculty of Engineering, Kyoto University, Kyoto)

\section{1 緒言}

電子顕微鏡透過法が開発され, 実物金属の内部組織 を直接観察することが可能になって以来, 疲労変形機 構の解明のために, 絽返し変形を受けた種々の材料の 転位組織の観察が多くの研究者によって行なわれてき た。 それとよると疲労変形を受けた金属材料の内部組 織は dislocation dipole る disloclation cluster, 年机に明確な cell structure の形成を特徵とするとされている。そして cell struc-

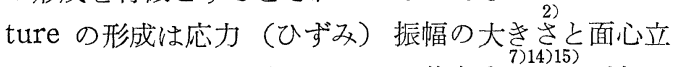
方晶金属では積層欠陥エネルギに依存することが知ら れている。体心立方晶系金属の場合は面心立方晶系金 属よりもすべり系が多い関係上, 疲学過程中の cell structure の形成はより一般的である・

一方，これらの内部組織と巨視的に測定される繰返 し塑性ひずみ挙動抢よび疲労損傷との間の関係につい ては，いまだに多くの不明な点が残されている。特に 前者は繰返し变形下の転位の運動を実験的に明らかに することが困難であるがゆ光に単純引張変形挙動の転 位論的解釈に比してょり難しい問題を含んでいる。し かし，この絽返し塑性ひずみ挙動に対する転位論的ア プローチの試みもなされている。後者の問題に対して は cell structure が疲労き裂の発生拉よび伝ぱと密 接な関倸沈あることが指摘されているが，疲学損傷と cell structure とを結び付けるための論理的な必然性 が必ずしも明確でない，この問題に対する現状は既に 解説がなされているのでここでは述べないことにする。

1950年代の終わり頃から現在にいたるまで内部組織 観察に基ら゙く疲労機構の研究が非常に多数なされてき たが，1970年頃からこの方面の研究も一つの曲がり角

* 原稿受理 昭和49年 3 月 22 日

** 正会員 京都大学工学部 京都市左宗区吉田本町
にさしかかった感がある，このあたりで過去に逆上っ てこの方面の研究を一望するのも研究のつぎの段階へ の発展を期待する意味で意義のあることと考劣てここ 飞筆を執った次第である。な秝絽返し加工硬化拉よび 軟化関してはすでに Grosskreutz によってすぐれ た解説がなされて拈り，本文に拉いても一部これを参 照したことを付言しておく.

\section{2 内部組織を支配する諸因子}

\section{$2 \cdot 1$ 結晶のすべり特性}

結晶のすべり特性は結晶表面に現われるすべり線の 形態を決定する。いわゆる wavy なすべり線とか, planar なすべり線とかいった言葉でとの形態が表現 されているのはよく知られているところである。この 形態は結晶中のらせん転位の交差すべりの難易によっ て決定される。したがって，体心立方晶金属では面心 立方晶金属や稠密六方格子金属よりも wavy なすべ り線形態を示すし, 面心立方晶金属では積層欠陥エネ ルギがその形態を決定する。稠密六方格子金属はその 意味で最も明確な planar なすべり線を形成すること になる。

繰返し变形によって形成される内部組織は上記すべ

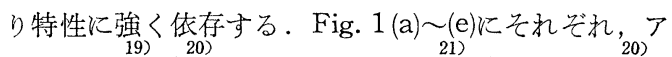
ルミニウム, 銅, 18-8ステンレス鋼, $\mathrm{Cu}-7.5 \% \mathrm{Al}$ 合 金拉よび鉄の高応力疲労飞おいて形成された典型的な 転位組織を示す，これより鉄では明確なセル組織が形 成されるが面心立方晶金属に祘いては積層欠宿エネル ギ，てが小さくなるほどセル組織の形態は不明確にな ることがわかる。すなわら高積層欠陥エネルギを有す るアルミニウムの場合にはセル壁は規則正しくポリゴ ン化した組織に近くなるのに対し銅の場合には dislocation 1oop を含を幅の広いるのとなる.さらに18-8 ステンレス鋼などのようにすべり特性がさらにplanar 


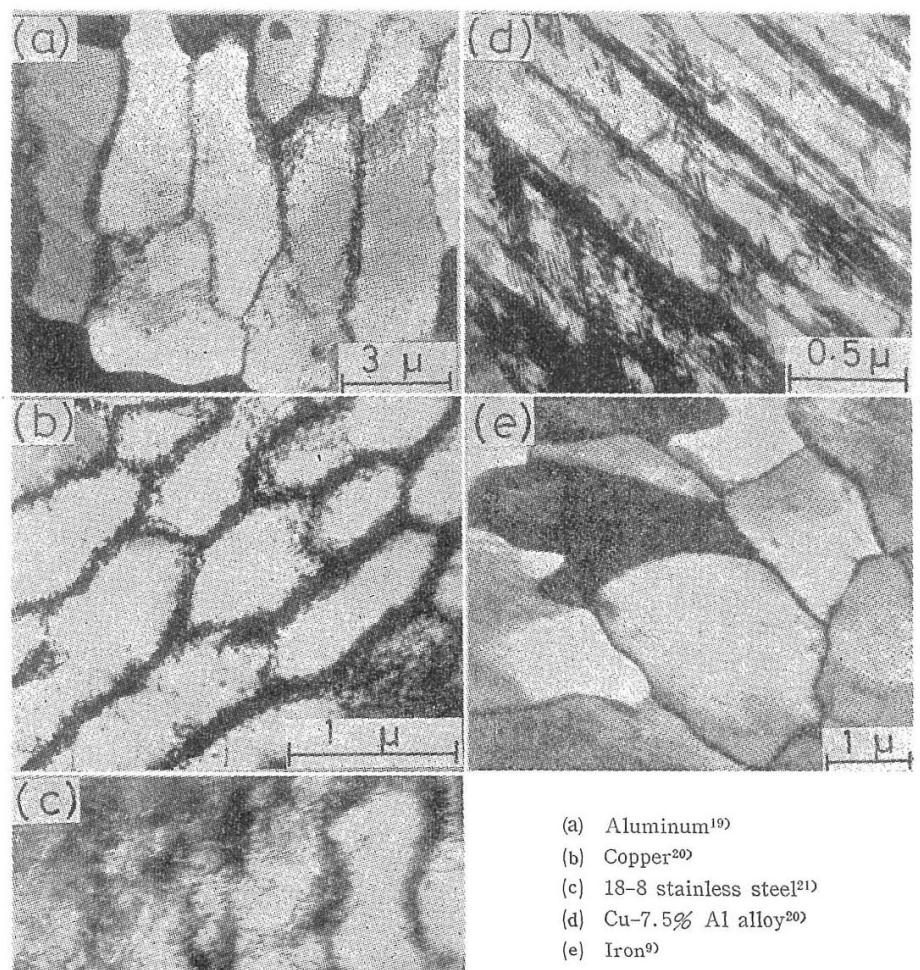

Fig. 1. Typical dislocation structures in various metals fatigued at high strain amplitudes.

型に近づくとセル壁構成転位の中で tangle 乙た転位 の占める割合が大きくなり、しかもセル内部にも多く の転位を含みセルの形態は不完全なものとなる、な肳 セルが形成されないような低応力振幅に上る疲労変形 に和いては wavy 型のものでは dislocation loop か ら成る debris が非常に発達するのに詨し planar 型 では dislocation multipole を多数含んだ tangled dislocation が规則的に主すべり面の trace の方向に 沿って配列した形態をとる。これらのすべり特性によ る転位の形態の相違は wavy 型金属に抬ける二重交 差すべり機棈による dislocation loop の形成拉よび

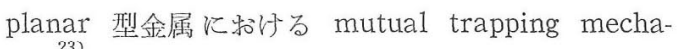
nism による multipole の形成により理解されうる。 な拈, $r \cong 7 \mathrm{ergs} / \mathrm{cm}_{20}^{2}$ の $\alpha$-黄銅や $\gamma=1.5 \mathrm{ergs} / \mathrm{cm}^{2}$ の $\mathrm{Cu}-7.5 \% \mathrm{~A} 1$ 合金注扬いてはいかなる条件下に拧 いてもセル組織は形成されない。

上では主として面心立方晶金属について述べたが体 心立方晶金属や稠密六方晶金属の場合子同栐飞理解 することができる。すなわち前者はアルミニウムなど の最子積層欠陥エネルギの高い材料汇詨応し, 後者は $\mathrm{Cu}-7.5 \% \mathrm{~A} 1$ 合金などの最もとの低い材料に対応した 内部組織を示可。
セル組織の形成に関しては種々の機構が提案されて いるがいまだに定説がケいのが現状である。 Seeger Lomer-Cottrell の不動転位に集積したらせん転位は 交差すべりを起こし反対符号の転位と合体してそのほ とんどが消滅するが，このとさ交差すべり面に形成さ れた邓状転位が小傾角境界を形成し，これが七ル壁を 構成する機櫣を考克た。しかし Hirsch はセル壁は小 傾角境界上りもむしろ転位の網目状組織から構成され ていることを報告し，也儿組織を,交差すべりを生じた らせん転位がエネルギ的に安定な状態に配列した結果 形成されたものと考克た。 尔た Kuhlmann-Wilsdorf らは㤝ら転位と点欠陷との相互作用を重視して，い わ㠴る mushrooming mechanism を提唱した。す なわら主すべり面上を運動するらせん転位がVacancy などの点欠陷之相互に作用し superjog p prismatic loop を形成する。このようにして形成された多くの jog 学有与る転位は運動するのが困難になり，そのら

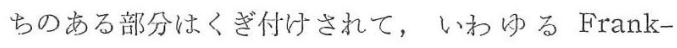
Read 源流の転位增殖源としての機能它果たすととに なる、さらに jog の部分の長さが充分大きいときには このような転位增殖源としての機能は主すべり面以外 の他のずり面にも及ぶことになるであるら。このよ 
らな転位源から増殖した転位はさらに他の点欠陥との

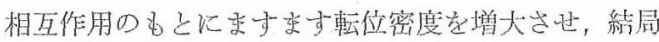
このような作用は負荷応力が転位ループを連動させる のに必要なそれより小さくなる上か，相互作用の源で ある点欠陷密度が非常に低くなるまで続く、セル壁は このようにしてできた転位により形成されることにな る。

またその後で Kuhlmann-Wilsdorf らは固執すべ り帯部分に形成されるセルの形成機棈を提案している。 ここでは上下の平行な主すべり面上を異なったバーガ ース・ベクトルを有する二つの dislocation loop が 払がる過程に打いて，それぞれのらせて転位部分が交 差すべり堊生じ，互い他のすべり面上に達する結果， 上下のすべり面上にはらせん転位による hexagonal network ができ（このときそれ朵れの主すべり面上 にある羽状転位の成分はその主すべり面に残留してい たらせん転位の運動により消隇している),さらにせ ルの側壁に相当する交差すへり面上には状状転位によ る傾角境界が形成されることを指摘している。

\section{$2 \cdot 2$ 応力振幅}

応力あるいはひずみの大きさ心転位の交差すべりや 多重すべりの顔度を支配する主要な要素の一つであり， したがって繰返し変形下に拈ける転位組織は応力振幅 あるいはひず质振幅に大さく依存する。た之えば銅の 疲学变形内部組織は高応力振愊 (破断繰返し数 $N_{f}=$ $10^{4}$ 105 サイクルに相当する応力レベル) では dislocation loop p dislocation dipole から成る明確なセ ル組織であるのに刘し低応力振愊 $\left(N_{f}=10^{6} \sim 10^{7}\right.$ に 相当する応力レベル）ではそれは形成されず主として dislocation 10op や dislocation dipole から成る带 状組織である。このことは銅より積層欠宿エネルギの 低い18-8ステンレス鋼 $\left(\gamma \cong 10 \mathrm{ergs} / \mathrm{cm}^{2}\right)$ に和いても 全く同様に認められる(Fig. 2). な和先述したように $\mathrm{Cu}-7.5 \% \mathrm{~A} 1$ 合金のように極端に

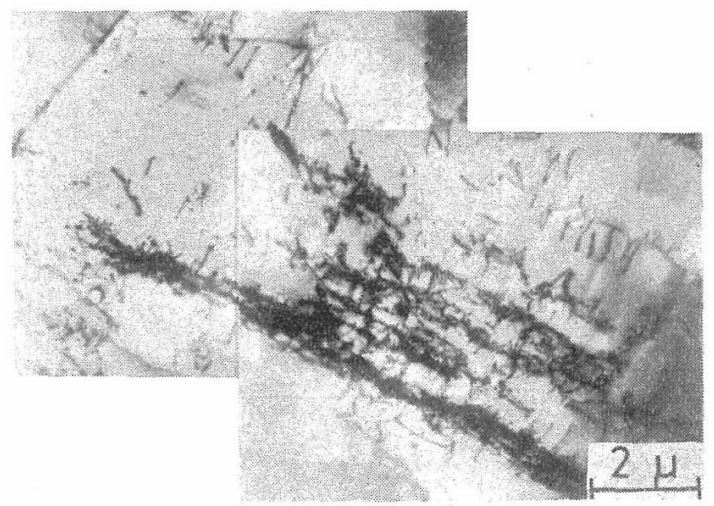

Fig. 2. Typical band structures in 18-8 stainless steel fatigued at low stress amplitude. ${ }^{21}$

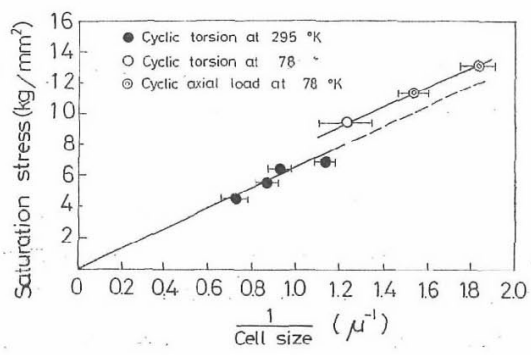

Fig. 3. Saturation stress versus (cell size) $)^{-1}$ in cyclic stressed copper polycrystals, 32 )

かなる高応力振幅下に蚂いてもセ儿組織は形成されず 転位は $\{111\}$ 面の trace に一致与る方向にかなり規 則正しく配列する (Fig. 1(d)).

セルの寸法のひずみ振幅低存性はPratt そ2) に研究されている．Fig. 3 珗銅について全びずみ振幅 を制御して繰返し変形試験を行なったときの加工硬化 飽和後の応力とセルの大ささとの関係を示す。これよ りセルの大きさ $l$ は応了振愊の增大に逆比例して減少 するのが認められる。また flow stress $て$ は，自由 転位の平均長さあるいはフランク・リード源の平均長

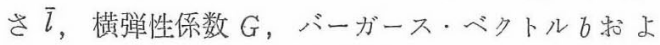

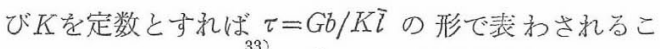
とが指摘されているのででセル内を動く転位長さと 考光れば Fig. 3 の結果は無理なく理解される。 Livingston は䞒の単結晶に対して分解せん断応力 $\tau$ は転位密度 $N$ の $1 / 2$ 乗に比例少ること定実験的に見い だして捻り（この関係は銅のみならず多くの材料につ いて一般的に成立すると考光てよい)，このことと先

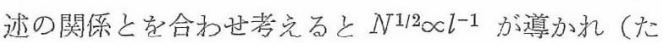
と究ば，Fig.4)，この関係もセル形状を立方体と仮定 した簡単なモデルを考えることにより説明されらる。 しかし後で述べるようにこのよらな考方方は絶対值的

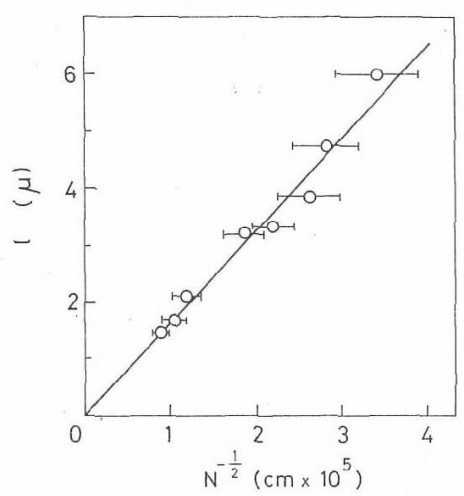

Fig. 4. The relation between dislocation cell size $l$ and the reciprocal square root of dislocation density $N^{-1 / 2}$ in copper. The cell size is a mean diameter. ${ }^{46}$ ? 
には問題を生ずる場合がある。

一方, Daniel ら゙は，銅に出ける，繰返し変形の結 果形成されたセ儿壁間あるいは dislocation cluster 間の寸法々変形応力との関係を, 自分の実験結果他他 の研究偣仙よって求められた結果を加兄て Fig. 5 のよ うに整理した。皇の結果は, てとしとの関係が実線によ り示されているよらに必ずしも $\tau \propto l^{-1}$ とはならずも しろ Abson らが指摘したように $\tau \propto l^{-3 / 4}$ となること がわかる。さらに Daniel は Seeger らとよって提唱 されている Long Range Theory に基づいて, $l=R_{0}$ ( $R_{0}$ は Long Range Theory 括ける superdislocation 同志間の距離）と扮いて変形応力を計算して点 線の結果を得ている。計算結果は実験結果とよく一致 して和り，これより彼は疲労硬化が Long Range Theoryによりよく説明できることを示した。

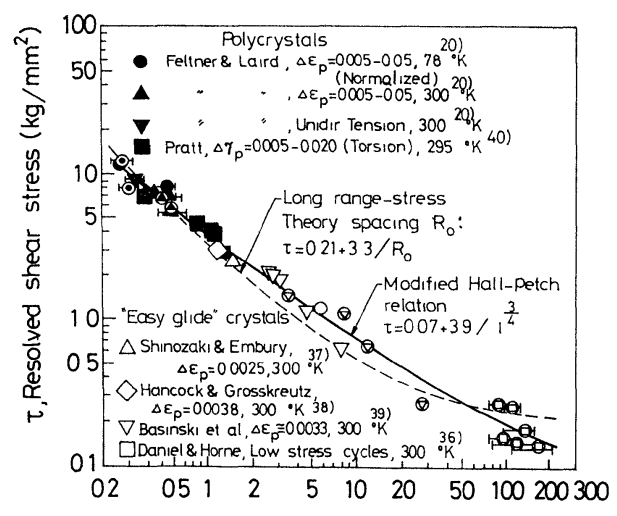

1, Inter-obstacle spacing in slip direction $(\mu)$

Fig. 5. Correlation of published cluster spacings (Shinozaki and Embury and Daniel \& Horne) and cell size with flow stresses. For polycrystals in uniaxial loading $\tau=\sigma / 3.1$ and in torsion $\tau=\tau_{\max } / 1.55$ Stresses at $78^{\circ} \mathrm{K}$ were reduced 7.5 pct to normalize to $300^{\circ} \mathrm{K}$. Circled points represent 5 pct cold worked samples (Feltner \& Laird) ${ }^{20}$ ) and data obtained by etch pittıng. 36 )39)

しかし Holt, Kuhlmann-Wilsdorf ${ }_{45}^{43)}$ 特よび Lang-

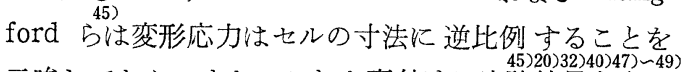
示唆して抒り, また, これを裏付ける実験結果も多い (Fig. 6) ${ }^{46)}$ ことから $\tau \propto l^{-1}$ と考光るのが一般的である 3 .

いずれにしてもての増大につれてしが減少すること は確かな事実であり，たとえばき裂近傍のセルの寸法 はき裂面からの距離の增大につれて大きくなる。すな わち，確かな事串としてき裂先端近傍のセルの大きさ は, 銓, アルミニウム合金, チタニウム合金で 0.1

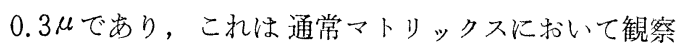

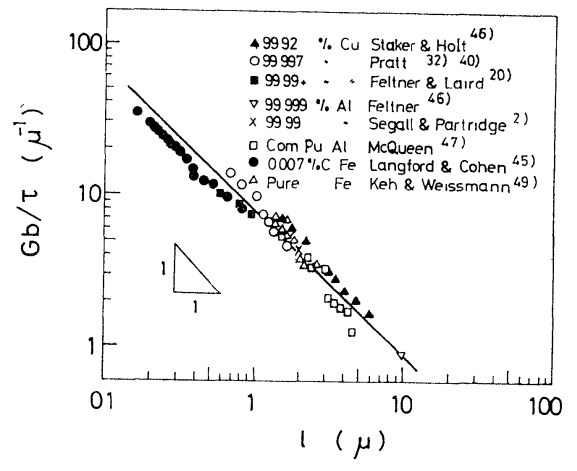

Fig. 6. Data from the literature connecting the normalized flow stress in shear $\tau / G b$ and the dislocation cell size $l$ on logarithmic coordinates. The shear moduli for copper, alum1num and iron were taken as 4.76, 2.7 and $7.56 \times 10^{3} \mathrm{~kg} / \mathrm{mm}^{2}$, respectively. The cell size $l$ of Refs 45) and 47) were converted from a mean intercept length to a mean diameter by multiplying by 1.68 . The variation of the modulus with temperature was not considered in plotting the data of Ref 47). The flow stress in shear $\tau$ was taken as $1 / 2$ the normal stress where appropriate ${ }^{46)}$.

される $3 \sim 4 \mu$ と比較すると 1 桁小さい.

\section{$2 \cdot 3$ 温度および繰返し速度}

試験温度の上昇はせ儿の形成を容易にし，かつ，七 ルの寸法を大きくする。このことは，高温はらせん転 位の交差すべりに対する臨界応力を減少させから, 転 位の上昇運動を容易にすることから理解できる。また， 高温でのすべり特性は低積層欠陥エネルギ材料に沶い ても planar 型から wavy 型に移行する事稘も高温 疲労变形により形成された内部組織が結晶のすべり特 性の観点から説明されらることを暗示している。

疲労変形によって形成される内部組織の温度依存性 を検討した研究は少ないが，引(張変形による内部組織 のそれはかなり詳細に調べられている。ここではその 一部を述べて疲学変形による内部組織の温度依存性の

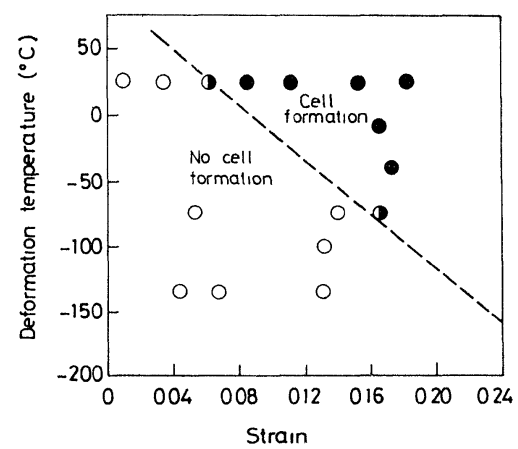

Fig. 7. Tendency for cell formation in iron as a function of strain and deformation temperature. ${ }^{49)}$ 
理解の助けとしたい.Fig. 7 は鉄多結晶のセル形成を 変形温度とひずみ量との関連に沶いて調べた結果であ る.白丸印はいかなるセルも形成されなかった条件を 示し, 黒丸はすべての結晶粒にわたって完全なセル形 成が認められた条件を示す，また右半黒丸は約50\%の 結晶粒にわたってセルが認められた条件であり，これ らを通る点線はセル形成50\%の大略の境界線を示して いることになる、これより明確なセル形成は変形温度 が低温になるほど，より多くのひずみ量を必要とする ことがわかり，この傾向は疲労变形の場合と一致する. セルの寸法の温度依存性をFig. 8 に示す。これはKeh \& Weissmann による鉄多結晶の整理結果に Staker \& Holt の銅の多結晶の結果打よび Swann によるア ルミニウムの結果を著者がつけ加えたものである。セ

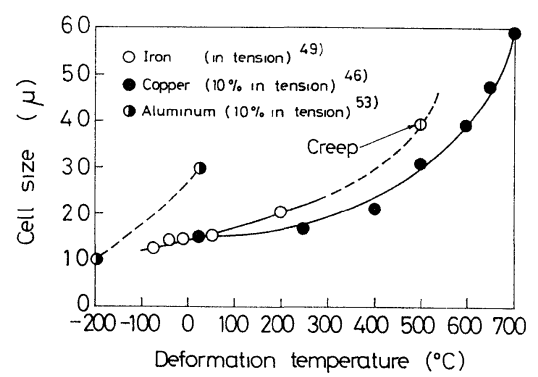

Fig. 8. Dependence of cell size on the deformation temperature.

ルの寸法は変形温度の上昇とともに増大することが明 らかである。一般的に低温での転位組織は高温の場合 のそれに比してょり一様な分布形態を示し個々の転位 は比較的直線状でしかも結晶学的なすべり面上に規則 正しく配列する傾向がある．また同じひずみ量に対す る転位密度は高温より低温に拉いて高い. Table I は 銅多結晶の $10 \%$ 引張変形後の転位密度の変形温度依存 性を示す。

疲労変形内部組織の繰返し速度依存性に関する研究 は非常に少ない. 最近 Abdel-Raouf \& Plumtree は 鉄多結晶について全ひずみ幅を制御した $\left(\Delta \varepsilon_{T}=0.01\right)$ 疲労試験を行ないその加工硬化挙動とその結果形成さ れるセルの寸法に及湾す繰返し速度の影響を検討した 結果を報告している。 Table II はその結果を示した もので, 繰返し速度の増大とともに加工硬化飽和後の 応才振幅 $\sigma_{s}$ は増大し, それに伴ってセルの寸法が減

Table I. Dependence of dislocation density of copper on the deformation temperature (10\% in tension). 46)

\begin{tabular}{l|r|r|r|r|r|r|r|r}
\hline $\begin{array}{c}\text { Temperature } \\
\text { of deforma- } \\
\left.\text { t1on ( }{ }^{\circ} \mathrm{C}\right)\end{array}$ & 25 & 250 & 400 & 500 & 550 & 600 & 650 & 700 \\
\hline $\begin{array}{c}\text { Dislocation } \\
\text { density (cm/ } \\
\left.\mathrm{cm}^{3} \times 10^{-8}\right)\end{array}$ & 120 & 90 & 68 & 29 & 20 & 14 & 13 & 85 \\
\hline
\end{tabular}

Table II. Relation between deformation rate $(\phi)$, saturation stress $\left(\sigma_{s}\right)$ and average cell size (l) for strain cycled iron at total strain range of 0.01 .54 )

\begin{tabular}{r|c|c}
\hline$\phi\left(\mathrm{sec}^{-1}\right)$ & $\sigma_{S}\left(\mathrm{~kg} / \mathrm{mm}^{2}\right)$ & $l(\mu)$ \\
\hline $0.2 \times 10^{-3}$ & 17.1 & $2.42 \pm 0.09$ \\
$2 \times 10^{-3}$ & 17.1 & $2.34 \pm 0.12$ \\
$40 \times 10^{-3}$ & 186 & $2.08 \pm 0.09$ \\
$120 \times 10^{-3}$ & 20.4 & $1.85 \pm 013$ \\
\hline
\end{tabular}

少するのが認められる。このセル寸法の繰返し速度依 存性は $\sigma_{s}$ の繰返し速度依存性を介してFig. 3 亿示し た形に整理できる.引張変形に拈いて形成される内部 組織の変形速度依存性については多くの研究があるが いまだに定量的な明確な結論は得られていないようで ある. 定性的にはセルの寸法は変形速度の増大ととも に減少し，かつあるひずみ量に対応する転位密度は高 速度変形の場合において低速度変形の場合より高い.

\section{3 繰返し加工硬化および加工軟化}

繰返し加工硬化とはひずみ振幅あるいは応力振幅一 定の条件下で材料に繰返し変形を与えたとき, 前者の 場合は応力振幅が繰返し数とともに次第に増加し, 後 者の場合にはひずみ振幅が次第に減少する現象をいう。 繰返し加工軟化とはその逆の現象である。これらはい ずれも繰返し変形過程中の内部組織と密接に関連して 拉り，それがゆ劣に上に述べた材料のすべり特性，応 力振幅, 温度拉よび繰返し速度などに直接支配される。 また疲労が応力あるいはひずみの逆転を伴ら現象であ るがゆえに繰返し加工硬化扣よび軟化の機構の解明は そのまま疲労破壞機構の解明につながるといっても過 言ではない。

\section{$3 \cdot 1$ 銅単結晶の繰返し加工硬化に対する結晶方位} 依存性

Fig. 9 は銅の繰返し加工硬化の結晶方位依存性を模 式的に図示したものである.これより繰返し加工硬化 には著しい方位依存性が認められ, その傾向は沶执よ そ次のよらにまとめられることがわかる．ステレオ三 角形のほぼ真中から〔110〕コーナーにかけての領域に 方位している結晶（領域A）は加工硬化は最も小さく きわめて平坦な加工硬化曲線を示す (curve 1). 一方, 領域 B とCの内の〔100〕特よび〔111〕近辺の方位の 結晶は最も加工硬化の程度は著しい(curve 2). また 〔100〕扣よび〔111〕近辺を除く領域B特よびCに才 位を有する結晶は上記領域Aと〔100〕および〔111〕 近辺の結晶がそれぞれ示す最小, 最大の加工硬化のち ようど中間的な加工硬化挙動を示す。すなわち領域 B の結晶は curve 3 , 領域 C に属する結晶は curve 4 によって示される変形挙動を示す。この内で特に領域 


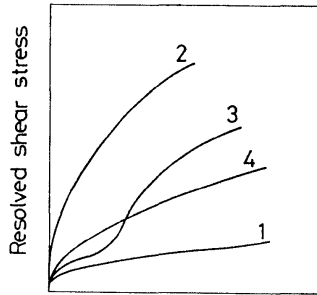

Number of cycles

(a) Typical cyclic hardening curves in copper single crystals

Fig. 9. Schematic representation of the orientation dependence of strain hardening in reversed deformation. Curve 1 is typical for orientation region $\mathrm{A}$, curves 3 and 4 represent transitional types in regions $B$ and $C$, respectively, which become more like curve 2 as the orientation approaches [100] or [111]. ${ }^{58)}$

Bに方位を有する結晶は二つの変曲点をるつ特徵的な 繰返し加工硬化特性を有寸る．そして加工硬化曲線の こう配が小から大へ移行する時期は結晶方位が〔100〕 一〔111〕境界拉よび〔100]-〔110〕境界に近づくにつれ て早くなる。一方，銅多結晶は領域 Bの方位を有する 単結晶と類似の繰返し加工硬化挙動を示す。繰返し加 工硬化の結晶方位依存性は加光られるひずみ振幅に大

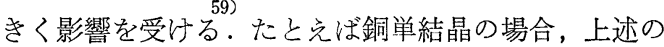
〔100〕および〔111〕付近の結晶が示すきわめて著しい 加工硬化は塑性ひずみ振幅 0.001 付近を境にして，そ れより小さい塑性ひずみ振幅では急激に低下する。ま た領域 Bの結晶の加工硬化曲線に打いて認められる二 つの変曲点の内，こう配が小から大へ移行するときの それは塑性ひずみ振幅が大きい場合には顕著に認めら れるが，低塑性ひずみ振幅の場合，たと党ば 0.004 のとき汇はそれは消失する。またきわめて低塑性ひず 又振幅（たと光ば 0.0001）の場合には綝返し加工硬 化に対する結晶方位依存性注ととんど認められなくな る。

上述の繰返し加工硬化に対する結晶方位依存性は引 張試験時の加工硬化に対するそれと同じ傾向を示す． そしてこれらの挙動はすべり系との関連に扔いて定性 的にはごく普通认矛盾なく説明でき，表面のすべり線 の観察結果もこの考光方と一致する。すなわち繰返し 加工硬化率の大きい方位の結晶では著しい secondary slip が認められ，逆に加工硬化率の小さいものでは primary slip line のみが観察される.

また内部組織的にもFig. 9 の領域A 嘱するような 単一すべり系の久が作用する方位を有する結晶ではと の primary slip plane の trace 方向に沿った带状の かなり規則正しい転位配列が観察されるのに対し，領 域Bの二重すべり系が働く結晶ではそれぞれに対応し
た二次元的なひろがりを有する転位組織が形成される ${ }^{60}$.

$3 \cdot 2$ 絽返し加工硬化および加工軟化に及ぼす結晶 のすべり特性および温度の影響

Fig. 10 は銅执よび銅一アルミニウム合金（銅にアル ミニウムを固溶させることによって積層欠陷エネルギ を变化させている）の繰返し定たわみ試験に打けるモ 一メントの增加率と材料の積層欠陷エネルギ $(\gamma)$ と の関係を示したものである。縦軸の $m=M_{0}{ }^{1000 \sim} / M_{0}{ }^{10 \sim}$ は繰返し数 $N=10$ サイクルのときに試験片に加觉ら れるモーメントと $N=1000$ サイクルのときのそれと の比であり，これは $N=10 〜 1000$ サイクル（加工硬 化過程の初期に相当する）の間に材料に生じた加工硬 化の程度を表わしている。この図より明らかなように 単結晶, 多結晶を問わず, 繰返し変形初期の加工硬化 量は $\gamma$ の増加とともに增大する。また，一般的に繰返 し変形初期の繰返し加工硬化率は 9 の大い材料に拉 いて大きく，乙か子繰返し加工硬化が飽和する時期は ケの大きい材料汪ど早いことがわかっている。

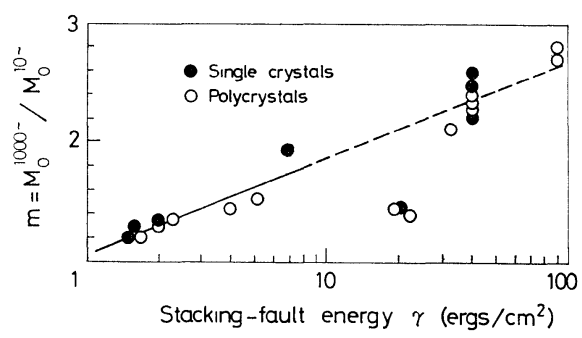

Fig. 10. Hardening parameter, $m$, vs. stackingfault energy, $\left.\gamma .{ }^{61}\right)$

温度を下げることはらせん転位の交差すべりを困難 にするといら点に执いて，材料の積層欠陥エネルギを 下げることに対応する。銅単結晶に塑性ひずみを制御 して引張，圧縮繰返し変形を与えたときの繰返し加工 硬化率の温度依存性を示したのが Fig. $11^{62)}$ である。縦 軸の $d \tau / d \Sigma\left|\gamma_{p}\right|$ は分解せん断応力一累積塑性ひずみ曲

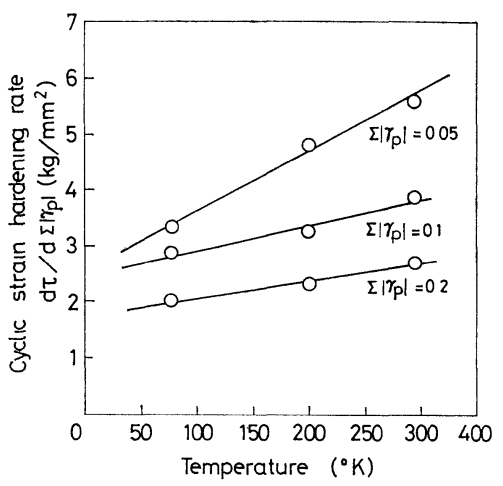

Fig. 11. Temperature dependence of the cyclic strain hardening rate of copper single crystals tested at $\left.\gamma_{p}= \pm 0.008 .62\right)$ 
線のこう配である。この図より繰返し変形初期に拈け る加工硬化率は試験温度が高いほど大きくなって扣り， この傾向は Fig. 10 に拈いてとを大きくした場合のそ れと定性的には一致する. しかも繰返し加工硬化が飽 和する時期は試験温度の低下とともに遅れることも， 上に述べたこの時期の $\gamma$ 依存性と一致する。

繰返し加工硬化が飽和した後に招ける応力幅と塑性 ひずみ幅の関係は cyclic stress-strain relation と 呼ばれ，材料の繰返し変形下の力学的性質を表わすも のとして一般によく知られている。この関係は普通， 両対数グラフ上で直線で近似することができ次式で表 現されることが知られている。

$$
\frac{\Delta \sigma_{s}}{2}=\sigma_{0}\left(\Delta \varepsilon_{p s} / 2\right)^{n}
$$

ここで $\Delta \sigma_{s}$ および $\Delta \varepsilon_{p s}$ はそれぞれ繰返し加工硬化 が飽和した後における応力幅と塑性ひずみ幅である。 上式に扣ける $\sigma_{0}$ と $n$ の值を $\mathrm{Cu}$ と $\mathrm{Cu}-7.5 \% \mathrm{~A} 1$ 合 金の $300^{\circ}$ 扎よび $78^{\circ} \mathrm{K}$ の温度下の繰返し変形試験で 求めた結果を Table III に示した。 これによると の比較的大きい銅 $\left(r \cong 50 \mathrm{ergs} / \mathrm{cm}^{2}\right)$ では焼なまし材， 予加工材にかかわらず，同一試験温度に対しては $\sigma_{0}$

Table III. Values of $\sigma_{0}$ and $n$ in equation $\Delta \sigma_{\mathcal{S}} / 2$ $=\sigma_{0}\left(\Delta \varepsilon_{p s} / 2\right)^{n}$ in copper and $\mathrm{Cu}-7.5 \% \mathrm{Al}$ stress-cycled on the various conditions. ${ }^{64}$ )

\begin{tabular}{|c|c|c|c|}
\hline Temperature & Material condition & $\begin{array}{c}\sigma_{0} \\
\left(\mathrm{~kg} / \mathrm{mm}^{2}\right)\end{array}$ & $n$ \\
\hline \multirow{2}{*}{300} & Cu-annealed $1 \mathrm{hr}$ at $450^{\circ} \mathrm{C}$ & 406 & 0.14 \\
\hline & $\begin{array}{c}\mathrm{Cu}-23 \% \text { reduction in } \\
\text { diameter }\end{array}$ & 406 & 014 \\
\hline \multirow[b]{2}{*}{78} & $\mathrm{Cu}$-annealed $1 \mathrm{hr}$ at $450^{\circ} \mathrm{C}$ & 819 & 019 \\
\hline & $\begin{array}{c}\mathrm{Cu}-23 \% \text { reduction in } \\
\text { diameter }\end{array}$ & & 019 \\
\hline \multirow{3}{*}{300} & $\begin{array}{c}\mathrm{Cu}-7.5 \% \text { A1-annealed } \\
1 \mathrm{hr} \text { at } 500^{\circ} \mathrm{C}\end{array}$ & 708 & 0.11 \\
\hline & $\begin{array}{l}\mathrm{Cu}-75 \% \text { A1-5\% } \\
\text { reduction in diameter }\end{array}$ & 644 & 007 \\
\hline & $\begin{array}{l}\mathrm{Cu}-75 \% \text { A1-23\% } \\
\text { reduction in diameter }\end{array}$ & 810 & 006 \\
\hline
\end{tabular}

および $n$ は同じ值を示すのに対し，rの非常に小さい $\mathrm{Cu}-7.5 \mathrm{Al}$ 合金 $\left(r \cong 1.5 \mathrm{ergs} / \mathrm{cm}^{2}\right)$ では cyclic stressstrain relation は材料の受けた前履歴の影響を強く 受け，烓なまし材和よび予加工材はそれぞれ固有の $\sigma_{0}$ 扣よびnの值を有することがわかる，後者の傾向は同 じくとのきわめて小さい $\alpha$-黄銅に拈いても顕著に認 められる。な和試験温度はとの大小を問わずそれぞれ の材料についてその試験温度固有の cyclic stressstrain relation を決定する。

Fig. $12(\mathrm{a})(\mathrm{b})$ は年々れぞれ，繰返し変形過程中心塑性 ひずみ振幅および試験温度を変化させた時それに伴っ て生ずる銅拉よび Cu-7.5 Al 合金の力学的変形挙動 の変化を示している。これによると銅に沶いては塑性 ひずみ振幅および試験温度を変化させた後の加工硬化
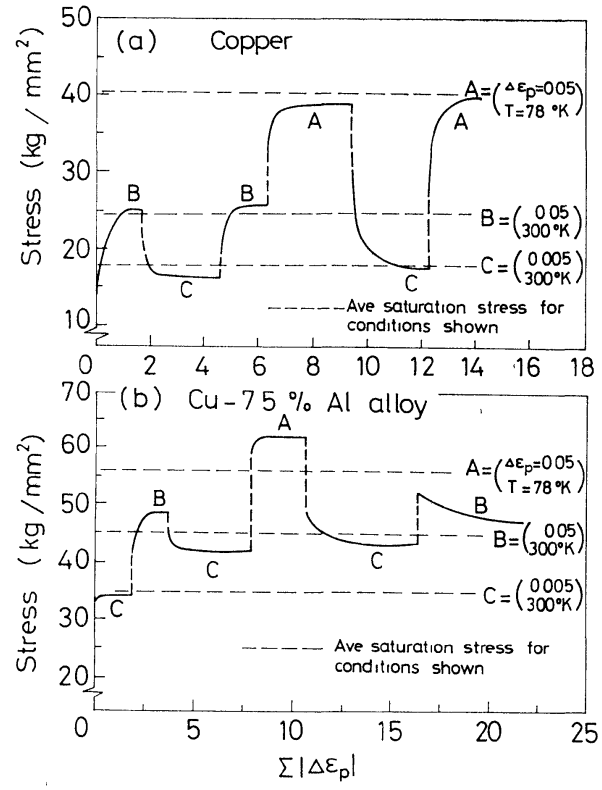

Fig. 12. Effect of change in amplitude and/or temperature on the saturation stress.

飽和時の応力振幅は加工硬化拉よび加工軟化の過渡期 間を経た後に，処女材に同一の試験温度で同一の塑性 ひずみ振幅を加光た時のそれにほぼ一致するのに対し， $\mathrm{Cu}-7.5 \% \mathrm{~A} 1$ 合金ではそれは明らかに前履歴の影響を 受け処女材のそれとは全く異なった值を示す。

上述のように, wavy なすべり形態を示す銅の繰返 し加工硬化飽和時の応力は塑性ひずみ振幅, 試験温度 および繰返し速度には依存するがその材料が前に受け た変形履歴には汇とんど影響を受けないのに対し planar なすべり形態を示す $\mathrm{Cu}-7.5 \% \mathrm{Al}$ 合金ではそ れは変形履歴に顕著な影響を受ける。これらの差は予 変形によって導入された転位配列およびその密度の， 以後の繰返し変形による変化が材料のすべり特性によ り支配されることを示唆するものであろら。事実 wavy なすべり形態を示す銅；極軟鋼の予加工材の内 部組織は以後の応力繰返し過程中に再配列して, 同一 条件で繰返し負荷を与えた焼なまし材の内部組織とほ ぼ同じ形態に変化することが実験的に確かめられてい る(たとえばFig.13). 。たこれらと類似のすべり特性 を有するアルミニウムについての応力変動疲労試験結 果によれば高応力疲労により形成された寸法の小さい セル組織はとの後の低応力疲労過程中に再配列执よび 一部の転位の消隇を通じて寸法の大きい七儿組織に変 化する. 一方, planar なすべり特性を有する Cu-7.5 \% Al 合金に稀いては予加工することにより導入され た転位組織は以後の応力繰返しに対して顕著な变化を 示さない(Fig. 14). このような転位の配列およびそ の密度の変化とすべり特性との関係は概念的には次の 


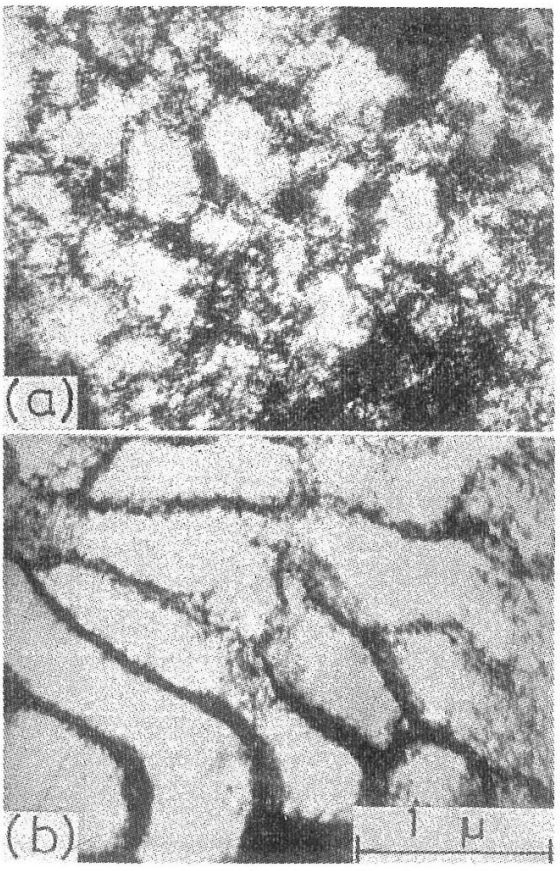

(a) Before strain cycling (b) After strain cycling

Fig. 13. Change of dislocation structure in cold worked ( $5 \%$ reduction in dia.) copper followed by strain cycling. 20)

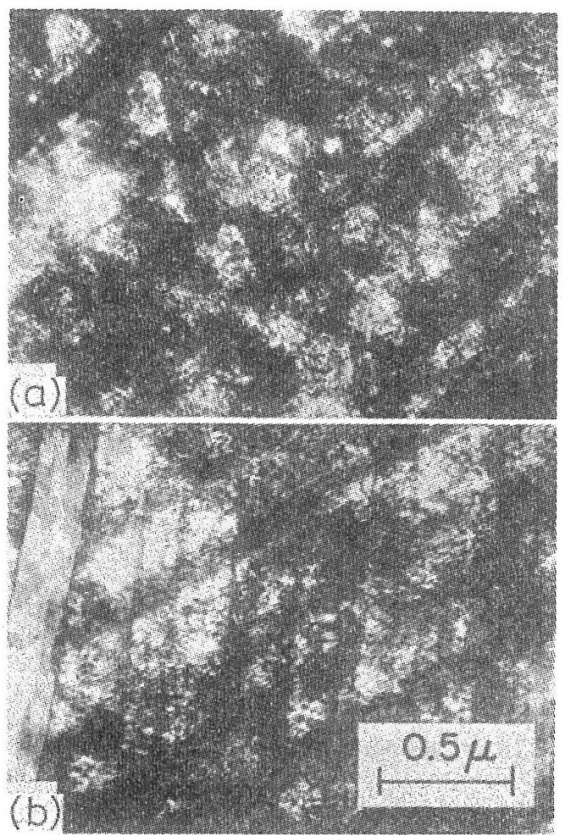

(a) Before strain cycling

(b) After strain cycling

Fig. 14. Change of dislocation structure in cold worked (5\% reduction in dia.) $\mathrm{Cu}-7.5 \% \mathrm{Al}$ followed by strain cycling. ${ }^{20}$
ように説明されらる。すなわららせん転位の交差すべ りが容易な前者の材料では転位は容易に 3 次元的な運 動学することが可能で市りそれがゆえに力学的条件に 応じて可逆的に転位は再配列寸ることがでさる。气れ に対し後者では転位の運動はほとんどが2次元的平面 に制限されるため転位の再配列はきわめて因難である。

このような内部組織観察結果は上に述べたそれ尔れ の材料の示古力学的挙動と符合する.

\section{$3 \cdot 3$ 繰返し加工硬化および軟化の機構}

Fig. 15 に模式的に示したよらに一般に金属材料の 繰返し加工硬化過程は, 繰返し変形の初期の, 加工硬 率の大きい rapid hardening stage, 加工硬化率が次 第に減少する transition hardening stage 打よび繰 返し加工硬率がほとんど0となり，繰返し加工硬化が 飽和卞る saturation hardening stage の三つの段階 に分けられることが实駼的に確かめら礼ている。一方， 繰返し加工軟化は定性的には Fig. 15 に示したよらに 加工硬化曲線を水平軸に関して対称に移動した形で進 行する. そして繰返し変形過程中の内部組織の変化と これら力学的举動と索関連させて金属材料の繰返し加 工硬化機構索説明する試みがなされている。な和緒言 でも述べたと特り逆負荷過程に扮ける転位の運動が明 確にわかっていない現在ではこれらの試みのほとんど が定性的議論にとどをっていることもまた止むを得な いことかも知れない。ここではこのような硬化和よび 軟化に刘与る考光方の現状を采とめて子たい。

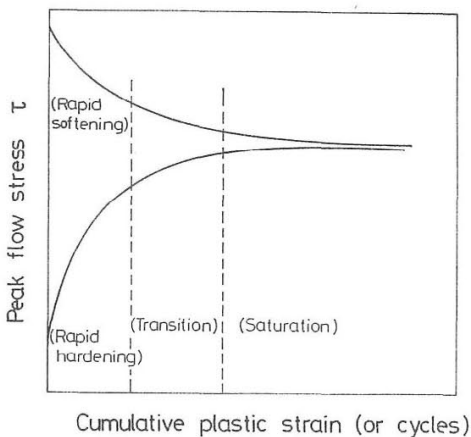

Fig. 15. Schema of a cyclic strain hardening and softening curve.

$3 \cdot 3 \cdot 1$ Rapid hardening Fig. 16 亿銅単結晶の rapid hardening stage に括子る典型的な転位組織を 示す、これは primary slip plane 上での観察結果 で㟧るが，このよらにこの段階での転位組織は主とし て primary burgers vector の方向である〔101]に

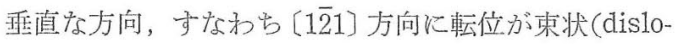
cation bundle) 飞集合した領域と転位が活とんど存

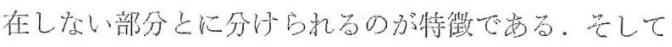
この dislocation bundle は主として互いに平行な主 


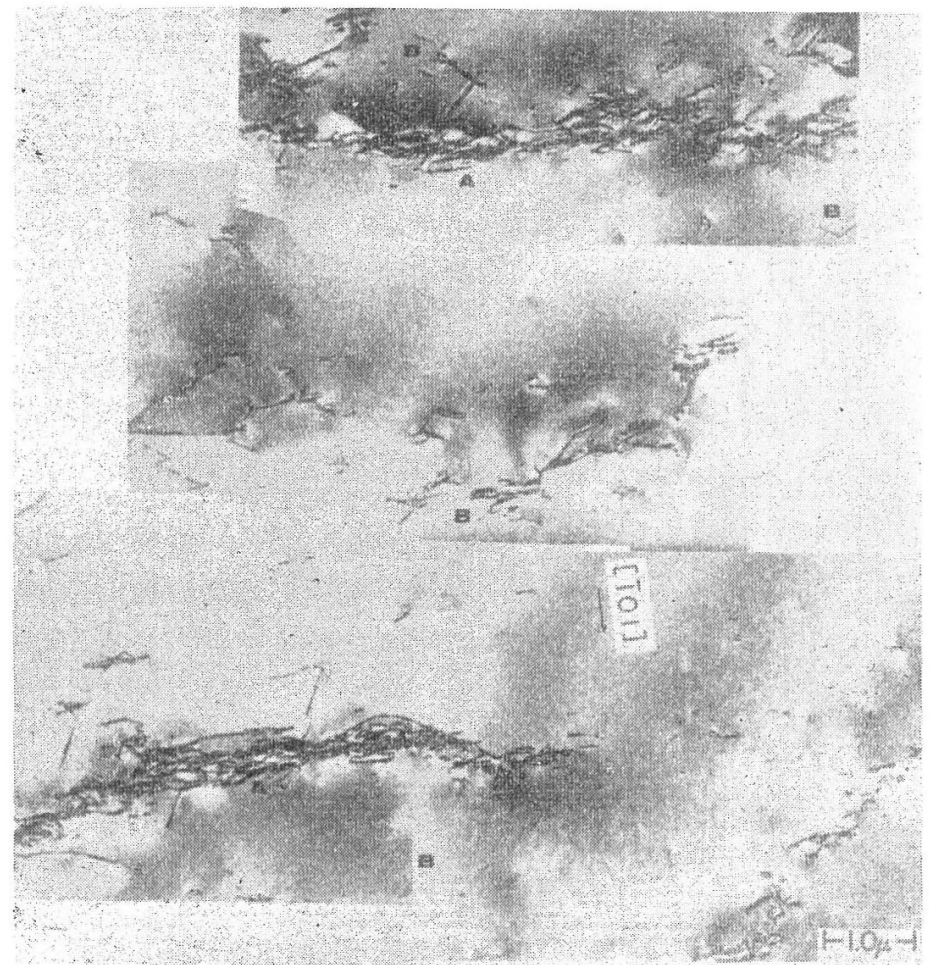

Fig. 16. Dislocation structure after $4 \frac{1}{4}$ cycles on primary slip plane of copper single crystal. $\Delta \gamma_{t} / 2=0.0075, T=300^{\circ} \mathrm{K}$. Typical dislocation bundles are observed. ${ }^{38}$ )

すべり面上の転位が互いに trapping し合った結果で きる, primary edge dislocation から成る dipole や multipole であることが知られている。このbundle にはこれに加えてジョグを有するらせん転位が交差す ベりを生ずることによりできた多数の prismatic dislocation loop p sessile is faulted $\langle 110\rangle$ dipole が含まれていることがわかっている。な执この段階で はらせん転位は繰返し変形過程中に交㫱すべりを生ず ることによりその大部分が消滅し，したがってこれは 涂とんど存在しない、Rapid hardening の進行とと もにこの dislocation bundle の部分の転位密度は増 加し, bundle 間の距離は減少する。さらにはこの

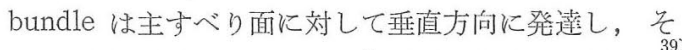
の結果その方向に沿った wall を形成する. Table IV は銅単結晶について累積望性ひずみ（鯐性ひずみ振愊 $\left.\Delta \gamma_{p} / 2=0.0033\right)$ の增加に伴う，主ずベり面上〔101〕 方向（主すべり系は（11)〕〔101〕）のbundle 間の距 離，bundle 部分（あるいは転位の密な部分）に持け る転位密度，転位の密な部分の全体部に詨寸る体積百 分率打上び平均転位密度の変化をまとめたものである。 な特表中“optical”とあるのはエッチ・ピット法に よって測定したことを意味している。これよりbundle 間の距離は累積塑性ひずみの增加とともに単調に減少 るすことが明らかである. Basinski らは繰返し塑性
Table IV. Change of wall separation along [101], dislocation density in dense region $\rho_{\bar{d}}$, ratio of volume of dense region to total volume and average dislocation density $\rho$ av. in fatigued copper single crystals with increasing of cumulative plastic resolved shear strain $\Sigma\left|\gamma_{p}\right|^{399}$.

\begin{tabular}{|c|c|c|c|c|c|}
\hline \multirow{2}{*}{$\Sigma\left|r_{2}\right|$} & \multicolumn{2}{|c|}{$\begin{array}{l}\text { Wall separation } \\
\quad \text { along }\{101\rceil(\mu)\end{array}$} & \multirow{2}{*}{$\begin{array}{c}\rho_{d} \\
\left(\mathrm{~cm} / \mathrm{cm}^{3}\right)\end{array}$} & \multirow{2}{*}{$\begin{array}{c}(\%) \\
\text { Occupied }\end{array}$} & \multirow{2}{*}{$\begin{array}{c}\rho_{\text {av. }} \\
\left(\mathrm{cm} / \mathrm{cm}^{3}\right)\end{array}$} \\
\hline & Optical & \begin{tabular}{|l} 
Electron \\
micro- \\
scopy \\
\end{tabular} & & & \\
\hline 0.0935 & 28 & & & & $7 \times 10^{8}$ \\
\hline 0.547 & 12 & 8 & $6 \times 10^{10}$ & 7 & $7 \times 10^{9}$ \\
\hline 1.335 & 8.5 & & & & \\
\hline 1.526 & 5.8 & 4.8 & $8 \times 10^{10}$ & 12 & $10^{10}$ \\
\hline 2.46 & 3.6 & 3.4 & $8 \times 10^{10}$ & 17 & $1.4 \times 10^{10}$ \\
\hline 4.91 & & 3.2 & & 25 & \\
\hline 5.85 & & 2.8 & & 27 & $2.9 \times 10^{10}$ \\
\hline 8.03 & & 2.6 & & 31. & $3.5 \times 10^{10}$ \\
\hline
\end{tabular}

ひずみスに伴う dislocation bundle の発達の様子を 3 次元的に検傠している。Fig. 17 は去の一例で，これ より) dislocation bundle が主ずべり面上のみならず それに垂直な方向へも発萑していることがわかる。な お rapid hardening stage の終わりの㭙期に执いて は，二次すべり录が働きだし，このため主として 〈121〉方向にのびた dislocation bundle は切断, 細 分化されて次第に，い水ゆる cell structure として 


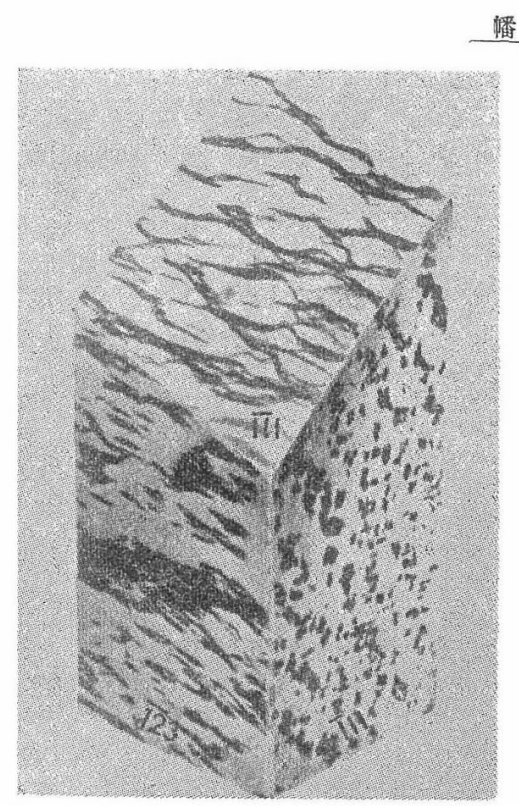

Fig. 17. Model showing the dislocation distribution in fatigued copper single crystal in three dimensions. Planes are indexed. ${ }^{39}$

の形態麦整完ていく.

以上の観察結果より rapid hardening は大略次の ように理解光れる。繰返し变形に上って生した転位は mutual trapping mechanism飞より互いに trap d れる、矢の後に新たに生した転位も气の部分につぎっ ぎと trap され、この結果 dislocation bundle が形 成される。繰返し変形に伴って dislocation bundle は主ずべ面上のみならず，それを直舟方向に対して も発達するとともに，いますで転位がほとんど存在し なかった部分にも，たと光ば sessile な fauited〈110〉 dipole 是捼点として新たに dislocation dipole が形 成される。このため bundle 間の距離,すなわら転位 の自由な運動距離は減少し，そのために与えられた塑 性ひずみを生じさせるに必要な応力は增加する。さら に応力の増加ととるに2 次すべり系が活動を始め，2 次すべり面上の転位は主ずべ面上飞発達した dislocation bundle 己交さしなケればならざ，このよらな

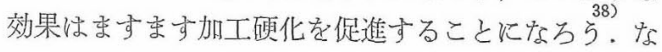
版上述の trapping mechanism とより生じた multipole の他にいわ功る交差すべり機構により形成され たと思わ礼る dislocation dipole や prismatic dislo-

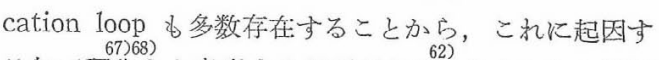

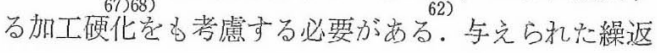

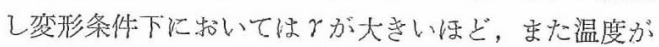
高いほど，交差すべりは容易になり，したがって prismatic dislocation 1oop 字容易に多数形成される。 このことはとの大きい材料ほど, をた試験温度が高い 潘ど rapid hardening stage の硬化㻭が大ざ ( Fig.
10 抢よび 11)といら結果定定性的飞都合よく就明する。

$3 \cdot 3 \cdot 2$ Saturation hardening この段階に拈い て形成される銅の転位組織を 3 次元的に検討した結果 によると, saturation hardening stage に扝ける転 位組織は rapid hardening stage 後期に和けるそれれ が連続的に発達した結果形成されるものと考光ら机， 主すべり面（たと光ば主すべり系を(111)〔101]とす る) に琹淔 (〔111〕) に明確な dislocation wall が形 成される，そしてこの wall の面は(101) であること が確かめられている。また I Iancock らは、すで先 に指摘されていたよらに, cell wall は primary slip planeのみならず critical 袄よびconjugate slip plane の traceの方向飞沿って配列して扔り，乙たがってこ の段階ではいわわる2次すべり系炕属する転位が多数 形成されることを確認している、このように saturation hardening stage の初期は rapid hardening stage に扮いて形成された, 主として2次元的な転位 配列が 3 次元的な cell 組織へと発迲与る過程に対応 すると考光ることができる、さら飞繰返し夜形が加光 られると cell wall はますます明確になるとともに cell wall を構成する転位の内で dislocation dipole や prismatic dislocation loop の占める割合がきわ めて大きくなる、そしてこのよらにして形成された転 位組織は以後の繰返し変形に対してきわめて安定で㐫 り, また以後転位密度も泟とんど増加しない。同じよ うな転位組織の変化過程は銅のみならず積層欠陌エネ ルギの低い18-8 ステンレス鋼の場合に的認められる。

な特, 以上の議論はいわわる高応力康労過程に刘応 するものである。低応力瘦労過程に括いては銅に打い ても cell は形成されず,その代わりに rapid hardening stage で形成された multipole から成る dislocation bundle が, 細分化されてできると思われる dislocation dipole p prismatic dislocation loop が patch 状にかたまって散在した転位配列となる。この patch と patch の間の距灕は応力振幅の増加につれ て減少する。

上述の钼察結果に基礼て saturation hardening

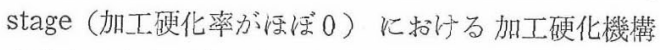
を考党るとき，少なくともこの過程に特いては転位密 度の增加率がほとんど0であるといら条件が满足され なけ机ばならない。この条件は, saturation hardening stage と批る応力あるいはひずみの繰返しの 1 サイクル中に，(1)引張過程に沶いて新たに形成された 転位が続く逆負荷過程において完全に消隇する, (2)引 張過程㧍よび压縮過程に拈いて同じ転位が可逆的にい わゆる to and fro motion をする, の二つのらちど ちらかの転位の運䡃を考光ることにより満足させられ る。現在この条件を満足する機構として主として次の 


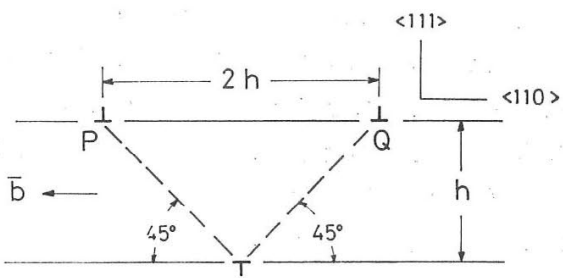

Fig. 18. View of prismatic dislocation loop flipping from one stable equilibrium position $P$ to other equilibrium position $Q$.

三つが提案されている。

Feltner は低応力疲労の場合に対して $h$ の間隔の主 すべり面上に配列した長さ $l$ の，互いに異符号の刃状 転位よりなる prismatic dislocation loop が flip-flop 運動（Fig.18）をする可能性のあることを指摘した Gilman の考方方を, 銅の疲労変形の説明に適用して 次のよらな結論を得ている。ここで loop の flip-flop 渾動とはFig. 18 に和けるPの位置にある刃状転位が 右方向に作用する応力により Qの位置に移動し, 逆に 左方向の応力により，Qの位置に移動した为状転位は 再びPの位置に戻るよらな転位の可逆運動を意味する。 したがって疲労に和ける応力の繰迈しに伴って刃状転 位はPとQの間を可逆的に往復運動するであろらとい うのが Feltner の考方无ある. Fig. 18 K和いて刃

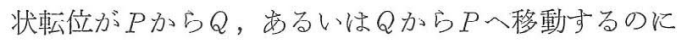
必要な応力 $\tau_{f 1 i p}$ は

$$
\tau_{\text {flip }}=\frac{G b}{8 \pi(1-\nu) h}
$$

ここでbはバーガース・ベクトル，惊ポアソン比， $G$ は横弾性係数である。おた $P$ からへの状転位の 移動により生ずる塑性ひずみ $\gamma_{p}$ は $\gamma_{p}=b(2 h l)$ で与兄 られるから, dipole の平均高さを党，艺の平均長さを $\bar{l}$ ，その可均密度をpとすればFig. 18 とからQへの 一行程中に生ずる塑性ひず㕛 $\gamma_{p}$ は

$$
r_{p}=2 \bar{l} \bar{h} p b
$$

となる. Feltner は銅について $G=4 \times 10^{5} \mathrm{~kg} / \mathrm{cm}^{2}, \nu$ $=0.3, b=2.55 \times 10^{-8} \mathrm{~cm}, \bar{h}=400 \AA$ として $\tau_{\mathrm{flip}}=$ $140 \mathrm{~kg} / \mathrm{cm}^{2}$ 走得，京た $\bar{l}=2000 \AA ， p=10^{15} \sim 10^{16}$ $100 \mathrm{ps} / \mathrm{cm}^{3}$ として $r_{p}=0.002 \sim 0.02$ 定算出している. これに対し銅単結晶のひずみ振幅 $\Delta r / 2=0.001 \sim 0.01$ に打当加工硬化飽和応力 $\tau_{8}$ は約 $200 \sim 300 \mathrm{~kg} / \mathrm{cm}^{2}$ であることから，上の計算で得られた $\tau_{\mathrm{flip}}$ は $\tau_{s} よ$ りかなり小さいこと，また $p=10^{15} \sim 10^{16} 1 \mathrm{oops} / \mathrm{cm}^{3}$ と いら数字は loop が一様に分布していると仮定しても 对状転位が 160 500 ̊ の間隔で存在することに対応 し，これは犼状転位同志の間隔が小さ過ぎるといら意 味において非現実的であるといら点などが指摘されて いる.

Watt らは応力西るいはひずみの繰返しに伴って生
ずる応力ーひずみのヒステリシスループを転位論的に 解釈するために，いわゆる dislocation shuttling モ デルを提出した。これはセル内あるいは bundle 間の きわぬて転位密度の低い領域を自由な転位が応才の繰 返しに伴って往復運動するといら考方方に基ついてい る。したがって転位の運動距離はセルの寸法あるい はbundle 閒の距離によって規定されることになる。 Hancock らは加工硬化が飽和した後の銅単結晶の内 部組織を観察した結果，Fig. 19 に示したように確か に cell wall 間にまたがった自由転位の存在气認め, これより dislocation shuttling モデルにより銅の saturation hardening の機構を説明している。すな わち $N$ を可動転位密度， $m$ を一つセル当たりの可動 転位の数, l学セルの寸法とすると塑性ひずみ $\gamma_{p}=$ $N b l=m / l^{2} \cdot b \cdot l=m b / l$ ¿なる. $\gamma_{p} \fallingdotseq \pm 0.0075, l=1.2$ ルとして $m \doteqdot 35$ を得ている。一方, ヒステリシ

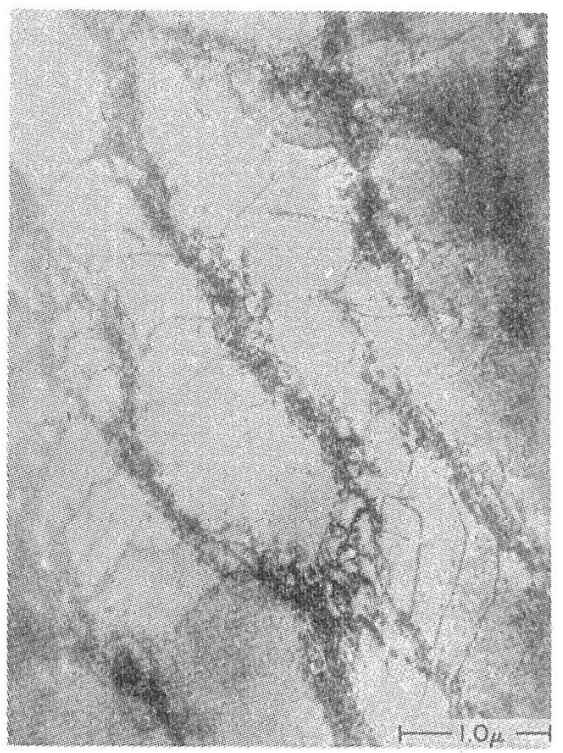

Fig. 19. Dislocation cell structure in copper characteristic of equilibrium fatigue structure at high strain amplitude. Dislocations straddling across cell walls are observed. ${ }^{38}$ )

ス・ループの面積とこのようなセル内を運動すること によって消費されるエネルギを等置して得た $m \doteqdot 85$ であり，この值は前者の約 2 倍である.このこ とよりヒステリシス・ループの面積の約 $50 \%$ に相当す るエネルギは塑性ひずみを生じさせる以外の仕事，た と党ば点欠陷の生成などに使用されると考学ている。 ひずみの点からは上のよらにかなり合理的な説明が得 られるが，このモデルほ応力に対してはかなり不都合 な結果学与劣る上のモデルに対して Frank-Read 型の転位の bowing 考考ると，加工硬化飽和後の 応力 $\tau_{s}$ 怔 


$$
\tau_{s}=\alpha \frac{G b}{l}
$$

となる、 $\alpha$ は $1 / 3$ 程度の定数である. $\tau_{s}=2.8 \mathrm{~kg} / \mathrm{cm}^{2}$ となり，これは央験的に得られる $\tau_{2}$ $\fallingdotseq 330 \mathrm{~kg} / \mathrm{cm}^{2}$ より1桁小さい. Feltner らはこの点 を考慮して応力は cell wall に执いてくぎ付けされて いる dislocation segment がセルの内部に bowing する応力として決定される考方を提案した。この場 合に打いては上式に拈いてl=1000 程度と考えれば $\tau \fallingdotseq 306 \mathrm{~kg} / \mathrm{cm}^{2}$ となり実験結果とほぼ等しくなる。乙 かしこの考光方に従えば, bowing する dislocation のらせん成分がすべて消隇すると仮定しても繰返し変 形に伴う転位密度の増加率は奏験值より 2 桁も大きい ことが指摘されて怙り，したがってこの機構が成立す るためにはサイクルごとに bowing する dislocation loop のほぼ99\%が消滅することを考えなければなら ない.

Piqueras 52は加工硬化への点欠陥の役割を重視し て加工硬化飽和後の変形応力を, point defect cluster が friction stress として作用することにより生ずる thermal component と，いわゆる転位同志の相互作 用に基づく long range な athermal component とに 分けて半定量的に検討している. その結果変形応力は 非常に高密度の点欠陷を含む cell wall に特ける転位 の運動によって決定されるのではなく，それは転位密 度の低いセル内を運動する転位が受ける, 点欠陥に起 因する friction stress と long-rangeな内部応力を打 ら破るために必要な応力とによって決定されることを 指摘した。 このモデルは, 先述の Hancock らの dislocations shuttling のモデルに拉いて応力を規定する 因子であった転位の bowing に，点欠陥による friction stress の因子を付子加えたものと解鄱すること ができる、したがって先の shuttling モデルの飽和応 力の計算值と契験値の約 1 桁の差はこの”friction stress を考慮することによりかなり減少することが 予想され興味深い。この点欠陷を重視した考方方は疲 労変形を受けた銅の引張試験に和ける降伏応力の温度 依存性が引張变形のみの場合のそれよりかなり大きい こと, 中性子を照射して点欠陷を多量に生ぜしめた銅 の降伏点の温度依存性が疲労変形材のそれとほぼ同程 度であること, 抢よび疲労変形により特に繰返し加工 硬化飽和時には prismatic dislocation loop の密度 がきわめて高いことなどから充分に現実性のあるもの と考觉られる。 ちなみに $78^{\circ} \mathrm{K}$ での降伏応力を $\sigma_{78}$, $300^{\circ} \mathrm{K}$ でのそれを $\sigma_{300}$ としたとき, $300^{\circ} \mathrm{K}$ で疲労変 形された後に引張変形を受けた銅では $\sigma_{300} / \sigma_{78}=0.71$ であるのに対し, 疲労変形時の応力振幅に等しい応力 まで予引張変形を与えた銅ではその比は 0.90 である。
以上, saturation hardening の機構を概観してき たが，実際の疲労過程においてはいずれの機構も充分 に現実性のあるものと考觉られる。いわばこれら三つ の機構が混合して作用していると考えるのが妥当であ ろう.そして，それらの割合については，たとえば dislocation loop の形成されやすい高積層欠陷エネル ギ材料では低積層欠宿エネルギ材料よりも flip-flop 機構が働く比率は大きいであろう. 逆に低積層欠陷エ ネルギ材料ではセル壁間あるいは bundle 間への転位 の張り出しが加工硬化を規定する割合が高いであろう． このように繰返し加工硬化に対しては各材料のすべり 特性をも考慮した柔軟な考方方が必要かと思われる。 また flip-flop 運動をも含めてこの過程に拈ける転位 の運動が完全に reversible であることも当然あり得 ない。もしそらであ机ば疲労破壊は永久に生じないこ とになる。

$3 \cdot 3 \cdot 3$ 繰返し加工軟化 繰返し加工軟化の機構 については明確な説明がほとんどなされていないのが 現状である.ただ $3 \cdot 2$ でも述べたように加工軟化が 顕著に現われる銅などの比較的交差すべりの容易な材 料では加工軟化過程中に転位の部分的消隇叔よび転位 の再配列が生ずることは実験的事実である。

Broom らは銅多結晶の予引張変形材に $293^{\circ}$ 拈よび $90^{\circ} \mathrm{K}$ で繰返し応力を負荷した結果, 前者の場合には 加工軟化が生じているのに対し後者ではとれがほとん ぞ生じないことを示した。この結果は疲労過程中に形 成される点欠陥の動さと関連付けて次のように説明す ることができる。すなわら疲労過程中に形成された点 欠陷（原子空孔）は転位の上昇運動を可能にする。そ れゆえこのような点欠陥が自由に動きうる試験温度下 では転位は容易に上昇運動をし，その結果予引張変形 により形成された、エネルギ的に不安定な転位配列は この上昇運動を通じて次第にポリゴン化し，ひずみを 解放すると同時にエネルギ的に安定した状態へと変化 する。これは予変形材から得られる broadening な 線回折班点が繰返し応力の増加とともに次第に明確な 微小班点に分離されるようになるといら細束X線回折 法による研究結果ともよく一致する。このような点欠 陷が動きうる温度は約 $220^{\circ} \mathrm{K}$ 以上であると考光られ， それゆ光, $90^{\circ} \mathrm{K}$ の試験温度下では軟化が観察されない， 上記実験結果を説明することができる。このよらな考 え方は中性子照射により点欠陥を生じせしめた銅単結 晶が加工軟化するといら実験事事とむ一致する。な特 結晶のすべり特性とこの軟化との関連については $3 \cdot 2$ においてもふれたよらに，交差すべりの容易な材料は それの困難な材料に比してこのような点久陥の生成が 容易であるとともに交差すべりそのものによる転位の 再配列が可能であるがゆえに加工軟化は容易である. 
Ham 尔はあらかじめ引張変形を与兄た銅単結晶が以 後の応力繰返しによって加工軟化を生ずる最小の応力 振幅の温度依存性が, 銅単結晶の変形過程に扔汸る stage III の開始応力 $\tau_{111}$ の温度依存性と全々同様な 傾向を有することを実験的化確かめた。この結果と表 面のすべり線の観察結果とを合わせ考兄ることにより， 加工軟化を生じうる最小の応力振幅は表面にstriation が生じ始めるそれと一致することを指摘した。この striation は主としてらせん転位の交差すべりを通じ て形成されることから加工軟化汶対してはこの交差す べりが最も重要な支配因子であることがわかる。なお， このような繰返し加工軟化は材料に繰返し塑性ひずみ が加兄られることが是非とも必要な条件である。この 最小の塑性ひずみは，たと党ば銅の場合，約 $8 \times 10^{-5}$ 程度であることが確かめられている。

\section{4 あ と がき}

以上, 疲労変形により形成される内部組織と繰返し 加工硬化および軟化の転位論的解釈に関する現状を概 観してきた．以下若干の問題点を述べて結言にかえた W.

種々の材料㧠よび試験条件下での疲学变形内部組織 の主要観察結果はすでに出つくした感じがしないでも ない，それにもかかわらず，この組織的情報を使用し て巨視的に計測される絽返し応力ーひずみ挙動を定量 的に説明することは現状ではほとんど不可能であるこ とが上述の結果から明らかであろう．単結晶の単純引 張変形下での加工硬化理論がいまだ確立していない現 在, このことはむしろ当然の帰結ともい兄る。しかし 不明な点はなにがしかの仮定をおいて材料の繰返し変 形下の力学的挙動を転位論的飞説明しょうとする試み は必要かと思わ机る。われわれはこの努力を重社てお り，その一部はすでに報告した。

内部組織と疲労損傷との関係については本文では全 くふれなかったがこれについては次のように考克る。 疲労損傷は直接的には材料の表面層に蓄積されるむ のであることは，たと党ば表面層の電解研摩による除 去が疲労寿命を著しく增大させる多くの実験結果から 明らかである。したがって疲労変形によって生ずるす ベり線の形態あるいはとのすべり線を構成する転位組 織に関する研究が重要であり，その試みは広く行なわ れている。一方，本文で述べた繰返し加工硬化招よび 軟化を決定するのは主として試験片内部のバルクとし ての転位であると考光ら机る。したがって繰返し変形 過程中に仏料が示す力学的挙動と疲労損傷を結びつけ るためには試験片内部の転位組織と表面層の転位組織 との関係を系統的に究明する必要があるう。試験片内 部の転位組織は表面層の転位組織の形態を決定し，ひ いては表面すべり線の形態を決定するといら意味に括
いてこの両者は結びっけられうるものと考光られる。 疲労変形の最大の特徵は繰返し塑性ひずみが加兄ら れるということである．絽返し加工硬化拉よび加工軟 化機構, それに疲労損傷の本質を探るため深渄と も応力あるいはひずみの逆転に伴ら転位の運動が明ら かにされなければならない。これが実験的に可能にな ったとき, 疲労損傷に直接奇与する転位の動きと, 寄 与しないそれとの区別が可能になり，それがゆ党に真 の意味での疲労破罜機構の解明が可能になるものと思 わ机る。

最後に本文をまとめるに際して種々有益な助言を賜 わった京都大学工学部山田敏郎教授飞深く感謝の意を 表する次第である。

\section{参 考 文 献}

1) Bollmann, W., Phys. Rev., 103, 1588 (1956).

2) Segall, R. L., and P. G. Partridge, Phil. Mag., 4, 912 (1959).

3) Segall, R. L., Electron Microscopy and Strength of Crystals, p. 515 (1963) John Wiley, New York

4) Waldron, G.W. J., Acta Met., 13, 897 (1965).

5) Feltner, C.E., Phil. Mag., 8, 2121 (1963).

6) Segall, R. L., P. G. Partridge, and P. B. Hirsch, Phil. Mag., 6, 1493 (1961).

7）たと党ば Grosskreutz, J.C., and P. Waldow, Acta Met., 11, 717 (1963)

8) McGrath, J. T., and W. J. Bratina, Phil. Mag., 12, 1293 (1965).

9) Klesnil, M., and P.Lukáš, J. Iron and Steel Inst., 203, 1043 (1965).

10) Lukáš, P., and M. Klesnil, Czech. J. Phys., B14, 600 (1964)

11) Lukáš, P., M. Klesnil, und P. Ryš, Z. Metallkunde, 135, 109 (1965).

12) Klesnil, M., M. Holzmann, P. Lukáš, and P. Ryš, J. Iron and Steel Inst., 203, 47 (1965).

13) Weissmann, S., A. Shrier, and V. Greenhut, Trans. ASM, 59, 709 (1966).

14）辛島誠一，及川 洪，小倉次夫，日本金属学会誌， 31, 669 (1967).

15) Avery, D. H., and W. A. Backofen, Fracture of Solids, p. 339 (1962) Interscience, New York

16）山田敏郎, 幡中憲治, 与川慎太郎, 日本機峨学会論文集 投稿中.

17）小倉次夫, 辛島誠一, 日本金属学会会報, 7, 423 (1970).

18) Grosskreutz, J.C., Phys. Stat. Solids, 47, 11 (1971).

19) Grosskreutz, J. C., J. Appl. Phys., 34, 372 (1963).

20) Feltner, C.E., and C. Laird, Acta Met., 15, 1633 (1967).

21) Hatanaka, K., N. Nakagawa, H. Kawabe, and T. Yamada, Proc. 14 th Jap. Congr. Mat. Res., 22 
(1971)

22) Johnston, W.G., and J.J. Gilman, J. Appl. Phy., 31, 632 (1960).

23) Steeds, J. W., and P. M. Hazzeldine, Discussions Farady Soc., 38, 103 (1964).

24) Segall, R.L., and J.M. Finney, Acta Met., 11, 685 (1963).

25) Partridge, P.G., Acta Met., 13, 517 (1965).

26) Seeger, A., Dislocations and Mechanical Properties of Crystals, p. 243 (1956) Johy Wiley, New York

27) Hirsch, P.B., R. W. Horne, and M. J. Whelan, Phil. Mag., 1, 677 (1956).

28) Hirsch, P. B., Internal Stresses and Fatigue in Metals, p. 139 (1959) Elsevier, New York

29) Kuhlmann-Wilsdorf, D., R. Maddın, and H. G. F. Wilsdorf, Am. Soc. Metals. Symposium on Strengthening Mechanism in Solids, p. 137 (1962).

30) Kuhlmann-Wilsdorf, D., E. E. Laufer, and H.D. Nine, J. Appl. Phys., 38, 896 (1967).

31) Feltner, C.E., and C. Laird, Trans. AIME, 242, 1253 (1968).

32) Pratt, J.E., Acta Met., 15, 319 (1967).

33) Kuhlmann-Wilsdorf, D., Trans. AIME, 224, 1047 (1962).

34) Livingston, J.D., Acta Met., 10, 229 (1962).

35) Daniel, R.C., Scripta Met., 4, 1015 (1970).

36) Daniel, R.C., and G. T. Horne, Metall. Trans., 2, 1161 (1971).

37) Shinozaki, D., and J.D. Embury, Metal Sci. J., 3, 147 (1969).

38) Hancock, J.R., and J. C. Grosskreutz, Acta Met., 17, 77 (1969).

39) Basinski, S. J., Z.S. Basinski, and A. Howie, Phil. Mag., 19, 899 (1969).

40) Pratt, J.E., J. Mater, 1, 77 (1966).

41) Abson, D. J., and J.J. Jonas, Metal Sci. J., 4, 24 (1970).

42) Seeger, A., S. Mader, and H. Kronmüller, Electron Microscopy and Strength of Crystals, p. 665 (1963) Interscience, New York

43) Holt, D. L., J. App1. Phys., 41, 3197 (1970).

44) Kuhlmann-Wilsdorf, D., Metall. Trans., 1, 3173 (1970).

45) Langford, G., and M. Cohen, Trans. ASM, 62, 623 (1969).

46) Staker, M.R., and D.L. Holt, Acta Met., 20, 569 (1972).

47) Feltner, C.E., Acta Met., 11, 817 (1963).

48) McQueen, H. J., J. Metals, 20, 31 (1968).

49) Keh, A.S., and S. Weissmann, Electron Microscopy and Strength of Crystals, p. 231 (1963) Interscience,
New York

50) Lukáš, P., M. Klesnil, and R. Fiedler, Phil. Mag., 20, 799 (1969).

51) Grosskreutz, J.C., and G.G. Shaw, Acta Met., 20, 523 (1972).

52）幡中憲治, 川辺秀昭, 山田朝治, 材料, 21, 212 (1972).

53) Swann, P.R, Electron Microscopy and Strength of Crystals, p.131 (1963) Interscience, New York

54) Abdel-Raouf, H., and A. Plumtree, Metall. Trans., 2, 1863 (1971).

55) Johari, O., and G. Thomas, Acta Met., 12, 679 (1964).

56) Nolder, R. L., and G. Thomas, Acta Met., 12, 227 (1964).

57) Edington, J.W., Phil. Mag., 15, 1189 (1969).

58) Paterson, M S, Acta Met., 3, 491 (1955).

59) Kemsley, D S., and M.S. Paterson, Acta Met., 8, 453 (1960).

60）たとえば Clarebrough, L. M., and M.E. Hargreves, Progress in Metal Physics, 8, 1 (1959).

61) Avery, D.H, and W.A. Backofen, Acta Met., 11, 653 (1963).

62) Feltner, C.E., Phil. Mag., 12, 1229 (1965).

63) Morrow, J., ASTM Spec. Techn. Publ., No. 378, p. 45 (1965).

64) Feltner, C.E., and C. Laird, Acta Met., 15, 1621 (1967).

65）幡中憲治, 山田敏郎, シンポジウム“疲労に括ける最近 の諸問題” p.124 (1973) 材料投稿中

66) 吉田 彰, 上村正雄, 川辺秀昭, 山田朝治, 材料, 18 , 1106 (1969).

67) Gilman, J.J., J. Appl. Phys., 33, 2703 (1962).

68) Fourie, J. T., and R. J. Murphy, Ph11. Mag., 7, 1617 (1962).

69) Wood, P. J., Phil. Mag., 28, 155 (1973).

70) Gilman, J. J., J. Phys. Soc., Japan, Suppl., 1, 172 (1963).

71) Watt, D. F., and R. K. Ham, Nature, 13, 734 (1966).

72) Piqueras, J., J. C. Grosskreutz, and W. Frank, Phys. Stat. Solids, 11, 567 (1972).

73) Broom, T., and R.K Ham, Proc. Roy. Soc., A251, 186 (1959).

74) Broom, T., and R.K. Ham, Proc. Roy. Soc., A242, 166 (1957).

75) 平 修二, 林 建吉, 田中啓介, 材料, 16, 32 (1967).

76) Adamson, R.B., Phil. Mag., 18, 681 (1968).

77) Ham, R. K., and T. Broom, Phil. Mag., 7, 95 (1962).

78）山田敏郎, 幡中憲治, 広瀬勇次, 日本機械学会関西支部 講演論文集, No.744-2, p. 58 (1974). 